$$
\begin{aligned}
& 994 \\
& \text { Ge } 7 \text { Lo } \\
& \text { copy z }
\end{aligned} \text { along. C. I. }
$$

The Economy of ground Squirrel Destruction wash. 


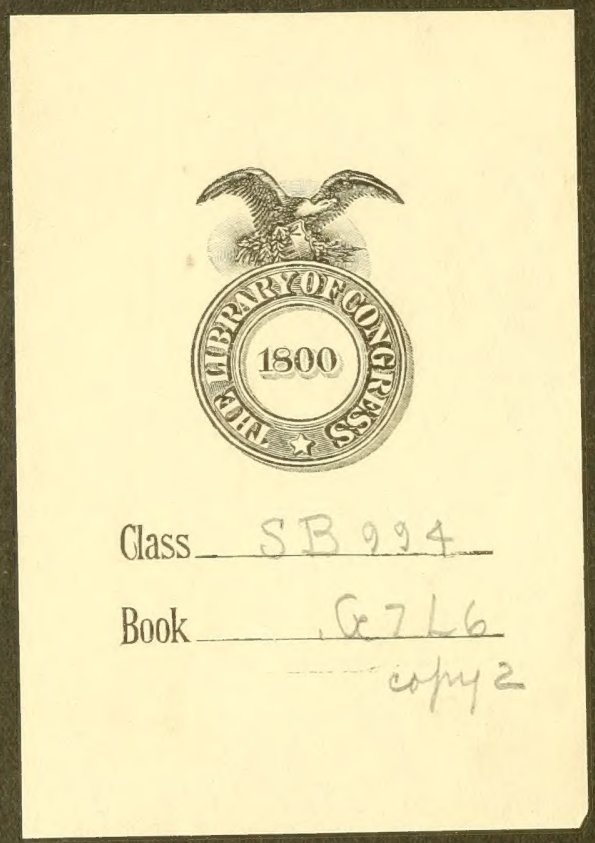


UNITED STATES PUBLIC HEALTH SERVICE

RUPERT BLUE, Surgeon General

\title{
THE ECONOMY OF GROUND SQUIRREL DESTRUCTION
}

\author{
BY \\ J. D. LONG \\ Surgeon, United States Public Health Service
}

REPRINT No. 238

FROM THE

PUBLIC HEALTH REPORTS

DECEMBER 11, 1914

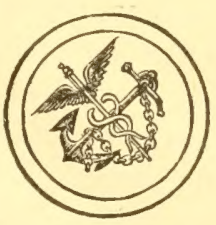

WASHINGTON

GOVERNMENT PRINTING OFFICE 1915

Monograph 
D. AF 0 .

JAH 201915 


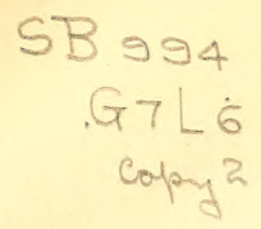

\section{THE ECONOMY OF GROUND SQUIRREL DESTRUCTION. ${ }^{1}$}

By J. D. Long, Surgeon, United States Public Health Service.

Every farmer or rancher who has had to contend with ground squirrels, gophers, or similar pests, has been aware for years that these animals have caused great losses each year through damage done by eating or destroying growing crops, such as hay, grain, fruits, nuts, vegetables, etc.; through damage to young trees, vines, and other nursery stock or seedlings; through damage to crops and fields that has resulted from flooding of the land due to breaks in irrigation ditches and canal banks, such breaks being due, in most instances, to burrows made into the banks by ground squirrels or gophers. Further, frequent interruptions to railroad traffic, and sometimes loss of life, have occurred through cave-ins in railroad cuts and washouts in embankments that have had their beginning through flood or surface water finding its way through a groundsquirrel burrow to a place where damage could result. In addition, even though washouts did not occur, subsidence of ties and rails took place, due to individual burrows or colonies eaving in, with resulting increase in maintenance-of-way charges and repairs to rolling stock and rails, due to pounding, and on rail ends and joints.

In California, from July 1, 1913, to November 1, 1914, the Publie Health Service has caused ground squirrels to be reduced about 90 per cent over an area of 3,373,146 acres, which includes about 2,000 miles of railroad right of way. The average cost for labor and materials has been about 17.4 cents per acre, and the average infestation has been about 6.5 squirrels per acre. From the above it is estimated that about 21,925,449 ground squirrels have been destroyed. As a result of the above-described operations, it is believed that bubonic plague has, for all practical purposes, been eradicated from the State of California and that any further danger of its spread has been removed.

During the progress of this work of squirrel destruction so many comments were made by farmers, landowners, ranchers, and others

${ }^{1}$ Reprint from the Public Health Reports, vol. 29, No. 50, Dec. 11, 1914. 
as to the savings that had resulted, that it was decided to make an attempt to collect data and see if any reliable conclusions could be drawn from the replies sent in. To this end a circular letter was addressed to supervising inspectors in charge of the various counties, accompanied by a supply of blank forms to be filled out by farmers, ranchers, and others. The circular letter and blank form are given below :

[Circular letter.]

\section{United States Public Health Service, \\ 111 New Montgomery Street, San Francisco, Cal., September 24, 1914.}

\section{To Supervising Inspectors:}

There are forwarded you, under separate cover, 250 blank forms, which you are directed to apportion between yourself and your field inspectors.

These blanks are to be taken to those landowners in the various districts who have effected practical squirrel destruction, with the request that for the good of the work and in the interest of its future continuance the questions on the blanks be filled out as accurately as may be possible and the blanks signed.

All the information furnished will be considered as confIDENTIAL as far as individuals are concerned, and only the total results of the investigation in each county will be used. Names of individuals will not be given out except by consent, as indicated on the blanks.

Signature is desired only as evidence of the authenticity of the report.

Instruct your field inspectors to render such assistance in filling out the blanks as may seem necessary or desirable, in order that the information obtained may be as nearly accurate as possible.

Supervising inspectors are directed to forward all complete blanks to headquarters as soon as they are received, in order that the compilation of the information may be proceeded with at once.
(Signed)
J. D. LoNG,
Surgeon in Charge Field Operations and Laboratory.

[Blank form.]

California, 191

It is requested that landowners and others supply the following information in order that the economic benefits of squirrel destruction may be more clearly known and in order that actual data on this subject may be compiled.

Give figures as nearly accurate as possible on property controlled by you.

Location of property: $\mathrm{T}_{----}, \mathrm{R}_{--\ldots}$, sec_..._- or _..... grant.

Total acres

Number of acres under cultivation

Number of acres in pasture

Number of acres wooded

LAND UNDER CULTIVATION.

Kind of crop-

Method used to destroy squirrels 
Amount of money expended in squirrel destruction (labor and material) $\$$

Estimated increase in crops due to the destruction of squirrels, as compared to previous years (in tons or pounds of crops)

What was the increase in crop worth?

Has your land increased in value, due to the destruction of ground squirrels (if so, how much per acre)?

PASTURE LAND.

Method used to destroy squirrels

Amount of money expended in squirrel destruction (labor and material) \$

How much has your pasture land increased in value, due to the destruction of ground squirrels?

Can you pasture more stock on your land, now that your squirrels are destroyed, than you could before?

If so, how many head?

Give the acreage of the pasture land on which your figures are based

REMARKS.

Under this heading give any other benefits that may have resulted from the destruction of squirrels, such as saving on repairs to canals or irrigation-ditch banks, savings on young trees or nursery stock, or on grain or other products that may have been stored for future use.

My name may be referred to in connection with this report, if deemed necessary.

(If it is desired that the name of the signer is not to be referred to, cross out the preceding sentence.)

(Sign here.)

From September 24, 1914, to November 1, 1914, 497 replies had been received. The information given had apparently been carefully compiled, and is believed to be as accurate as can be obtained.

Only the increase in crop is taken into consideration, this increase being figured on the basis of the average crop for preceding years, when ground squirrels were present and taking their annual toll.

The 497 replies received represent a total area of 321,233 acres; the total sum reported as expended for squirrel destruction over this area amounted to $\$ 36,091.85$, or an average of 11.2 cents per acre; the value of the savings realized over this area from the destruction of ground squirrels amounted to $\$ 109,301.50$, or an average saving of 34 cents per acre, which represents a return of 303.5 per cent in the first year.

To illustrate the savings on each particular type of crop or industry, the following figures, taken from the returns as compiled, are given: 


\section{Cultivated Lands.}

171 persons saved 1,746 tons of hay value__ $\$ 15,890.50$

249 persons saved $2,415.4$ tons of grain do $50,144.50$

76 persons saved 208.5 tons of fruits do $5,338.50$

15 persons saved 18,395 pounds of nuts $1,882.00$ 36 persons saved 287 tons of vegetables do 4, 026.00

Three hundred and seventy of the above persons estimated that their land had increased in value $\$ 2.74$ per acre as a direct result of squirrel destruction. (This figure of $\$ 2.74$ per acre increase in value has not been included in the total savings of $\$ 109,301.50$ given above.)

\section{Pasture Lands.}

One hundred and fifty-two persons reported that 2,163 more head of cattle could be pastured on 150,845 acres of pasture land than could be pastured before squirrels were destroyed, or 1 additional horse or cow to each 69.7 acres of pasture. This saving alone, estimated at the usual figure of $\$ 1$ per month per head, represents a saving of $\$ 25,976$.

One hundred and sixty-eight persons estimated that their pasture land had increased in value $\$ 1.17$ per acre as a direct result of squirrel destruction. (This figure of $\$ 1.17$ per acre has not been included in the total savings of $\$ 109,301.50$ previously given.)

\section{Various Savings.}

Twenty-one persons reported savings of $\$ 2,331$ in repairs to irrigation canal banks, but made no estimate as to losses due to flooding in previous years. Average saving per person, $\$ 111$.

Thirty-six persons reported "great savings on repairs to ditch and canal banks," but made no estimate of the amount saved.

Twenty-two persons reported savings of $\$ 2,188$ on young trees, an average of $\$ 99$ per person.

Nine persons reported savings of $\$ 1,525$ on grain and other products that were kept in storage in granaries, etc.; average saving, $\$ 169.44$ per person.

The great majority, under the heading of remarks, expressed their satisfaction with the results obtained and hoped that the work would be continued until ground squirrels were entirely eliminated.

It is thoroughly realized by all interested parties that, to obtain good and satisfactory results of a permanent nature in work of this character, the Federal, State, and county governments and the people themselves must work in complete and harmonious cooperation through some such organization as has been at work during the past year. 


\section{Summary.}

Replies recelved

Amount expended in squirrel destruction on 321,233 acres $\$ 36,091.85$

Amount expended per person.

$\$ 72.61$

Amount saved as a direct result of squirrel destruction $\$ 109,301.50$

Amount saved per person

$\$ 201.81$

ADDITIONAL COPIES

OF THIS PUBLICATION MAY BE PROCURED FROM

THE SUPERINTENDENT OF DOCUMENTS

GOVERNMENT PRINTING OFFICE

WASHINGTON, D, C.

AT

5 CENTS PER COPY 

LIBRARY OF CONGRESS

|||||||||||||||||||||||||||||||||||||||||||||||||||

00008 79098 A 